\title{
Mineral content and antioxidant compounds in strawberry fruit submitted to drough stress
}

\author{
Ellen Cristina PERIN ${ }^{1,2}$, Rafael da Silva MESSIAS ${ }^{2}$, Vanessa GALLI ${ }^{1,2^{*}}$, Joyce Moura BOROWSKI ${ }^{1,2}$, \\ Esmael Rickes de SOUZA ${ }^{1,2}$, Liziane Oliveira de AVILA ${ }^{1,2}$, Adilson Luis BAMBERG ${ }^{1}$, Cesar Valmor ROMBALDI ${ }^{2}$
}

\begin{abstract}
Due mainly to the taste and appearance, the strawberry stands out in relation to the other fruits. and for the presence of antioxidant compounds. However, little attention has been devoted to the impact of abiotic stresses on the quality of strawberry and its agronomic performance. In the present study, we evaluated the effect of two levels of DS (L1 - 70\% and L2 - 50\% of crop evapotranspiration) on the quality of strawberry fruit and on some agronomic and physiological variables. There was a dose-dependent reduction in the evaluated agronomic variables in the DS plants, and the content of some minerals in the fruit and leaves was modified. The activities of the oxidative enzymes were higher in the fruit of L2 treatment, and the content of sucrose, reduced sugars, phenolic compounds and the total antioxidant activity were increased in the fruit from L2 treatment; while those of anthocyanins and L-ascorbic acid were reduced in L1 and L2 treatments, respectively. The phenylalanine ammonia lyase gene was upregulated and other genes related to phenylpropanoid and ascorbate pathways were downregulated in the fruit of stressed plants. Thus, our results indicate that DS seems to be a promising strategy to improve the content of antioxidant compounds and sugars.
\end{abstract}

Keywords: Fragaria $\times$ ananassa; food quality; drought stress; antioxidant; mineral content.

Practical Application: Drought stress might be applied to induce antioxidant and sugars in strawberry fruit.

\section{Introduction}

The frequency of the periods of drought and limited availability of water resources for crop production has negatively affected agricultural production. A plant experiences drought stress (DS) either because of insufficient water supply to roots or because of very high transpiration rates (Anjum et al., 2011). The induction of antioxidant compounds in the edible part of plants grown under such adverse conditions are well documented (Ali et al., 2013; Złotek et al., 2014), and are of particular interest due to the potential health benefits associated with their consumption (Fiedor \& Burda, 2014; Shahidi \& Ambigaipalan, 2015). Therefore, it has been proposed that regulated deficit irrigation is a promising strategy to improve the content of functional compounds in fruit and to stimulate plant adaptation to stress-prone environments. Moreover, this type of irrigation represents a sustainable strategy to reduce water usage (Laribi et al., 2013).

Due to its sensory characteristics (mainly flavor, color and general appearance) and because it has nutritional compounds with antioxidant potential, strawberry is among the most popular fruits (Giné-Bordonaba \& Terry, 2010). Moreover, the general quality of strawberry fruit is also dependent, among other factors, on the content of minerals and sugars (Rahimi et al., 2011). Therefore, it is worthy to investigate whether DS affects the quality of strawberry fruit by modifying the content of antioxidant compounds, minerals, and sugars.
In the study reported by Sun et al. (2015), strawberry plants under drought stress showed leaves with increased content of malondialdehyde, proline, sugar and higher activity of peroxidase, catalase and superoxide dismutase then leaves of control plants. Higher content of proline and higher activity of ascorbate peroxidase and gluthationa reductase was also observed in leaves of strawberry cultivars after drought stress induced by poliethyleneglycol (Gulen et al., 2018). According to Terry et al. (2007), some taste-related (monosaccharides and sugar/acid ratios) and health-related compounds/parameters (antioxidant capacity and total phenolics) were generally much greater in fruits from plants cultivated under deficit irrigation (DI). Similarly, the quality (greater sweetness and sugar/acid ratio) of strawberry fruit was improved in plants cultivated under DI in the study performed by (Giné-Bordonaba \& Terry, 2010); although, this effect was cultivar dependent. Therefore, it is well known the effect of drought stress on the accumulation of some antioxidants and quality-related compounds in strawberry fruit; however, no other studies, to the best of our knowledge, have investigated the impact of this strategies both at the molecular and biochemical level as well as its possible relationship with some agronomical variables and/or the altered mineral composition. However, agronomic variables related to the overall quality of strawberry fruits submitted to water stress were evaluated for their effects. In addition, the relative expression of the genes 
related to fruit quality was also evaluated to gain important insights into the mechanisms involved in the response of DS on strawberries.

\section{Materials and methods}

\subsection{Plant material and cultivation}

The plants were grown in a greenhouse in Pelotas/RS/Brazil ( $31^{\circ} 41^{\prime} 08^{\prime \prime} 5$ and $52^{\circ} 25^{\prime} 56^{\prime \prime} 0,42$ m altitude). Strawberry seedlings 'Camarosa' were transplanted and grown under the same conditions of fertilization carried out in a previous study (Galli et al., 2016). Irrigation was performed daily by the drip method, and the volume of water supplied was adjusted weekly. The evapotranspiration value was calculated using the temperature and relative air humidity of the greenhouse and was monitored daily through a data-logger (Icel Manuas, HT-4000 model). We checked the equivalent Kc (crop coefficient) at each stage of the development of the plants. The relative humidity of the soil in each pot was also monitored twice a week using a hygrometer, Hidrofarm (Falker, HFM 2030 model), in order to perform tiny adjustments in the supply of water; therefore, the relative humidity of the pots was always maintained between 16-19\%. The experimental design was completely randomized with four replicates per experiment and six plants per replicate. The treatments were as follows: C- control/ without stress and two levels of the drought stress, L1 - DS level 1 and L2 - DS level 2, corresponding respectively to $100 \%, 70 \%$ and $50 \%$ of crop evapotranspiration (ETc). The application of the stresses was initiated 109 days after transplantation (beginning of the flowering stage) to 212 days after the start of the experiment (end of the crop cycle). Mature fruit (fully red, according to Jia et al., 2013) were sampled at the final stage of the crop production (Figure 1). The samples (mature strawberries) were stored in an ultra freezer at $-80{ }^{\circ} \mathrm{C}\left(\right.$ Forma $^{\mathrm{T} m} 900$ Series-Thermo Fisher Scientific, model 907/Brazil) and freeze-dried in a lyophilizer (LIOTOP Liobras L108/Brasil) to carry out analysis of the fruit quality. The leaves used for the analysis of the mineral content were a correspondent at the end of the experiment with all the leaves of the plant. For all determinations, the four field replicates and three analytical replicates were used.

\subsection{Photosynthetic variables, soil electrical conductivity, fruit yield and plant biomass}

Variables related with the photosynthesis were evaluated with a portable gas exchange fluorescence system infrared gas analyzer (IRGA) (Heinz Walz GmbH, GFS 3000 model/Germany): transpiration rate (E), $\mathrm{CO}_{2}$ assimilation rate $(\mathrm{A})$ and stomatal conductance $\left(\mathrm{GH}_{2} \mathrm{O}\right)$. Six measurements ( $\mathrm{M} 1$ to $\mathrm{M} 5$, as shown in Figure 1) in fresh, fully-developed leaves were performed during the crop cycle. The electrical conductivity of the soil was evaluated in samples collected randomly from all the six pots of each biological replicate, using a conductivity meter (Tecnal, TEC-4MPP model/Brasil). Two measurements were performed during the experiment, as explained in Figure 1: $\mathrm{S} 1$ corresponded to one month after the beginning of DS, and S2 corresponded to the end of the experiment. To perform the measurements, $5 \mathrm{~g}$ of dried soil were diluted in $50 \mathrm{~mL}$ of distilled water (1:10). For determination of the crop yield, ripe fruit of all the plants were collected and weighed for the whole duration of the crop

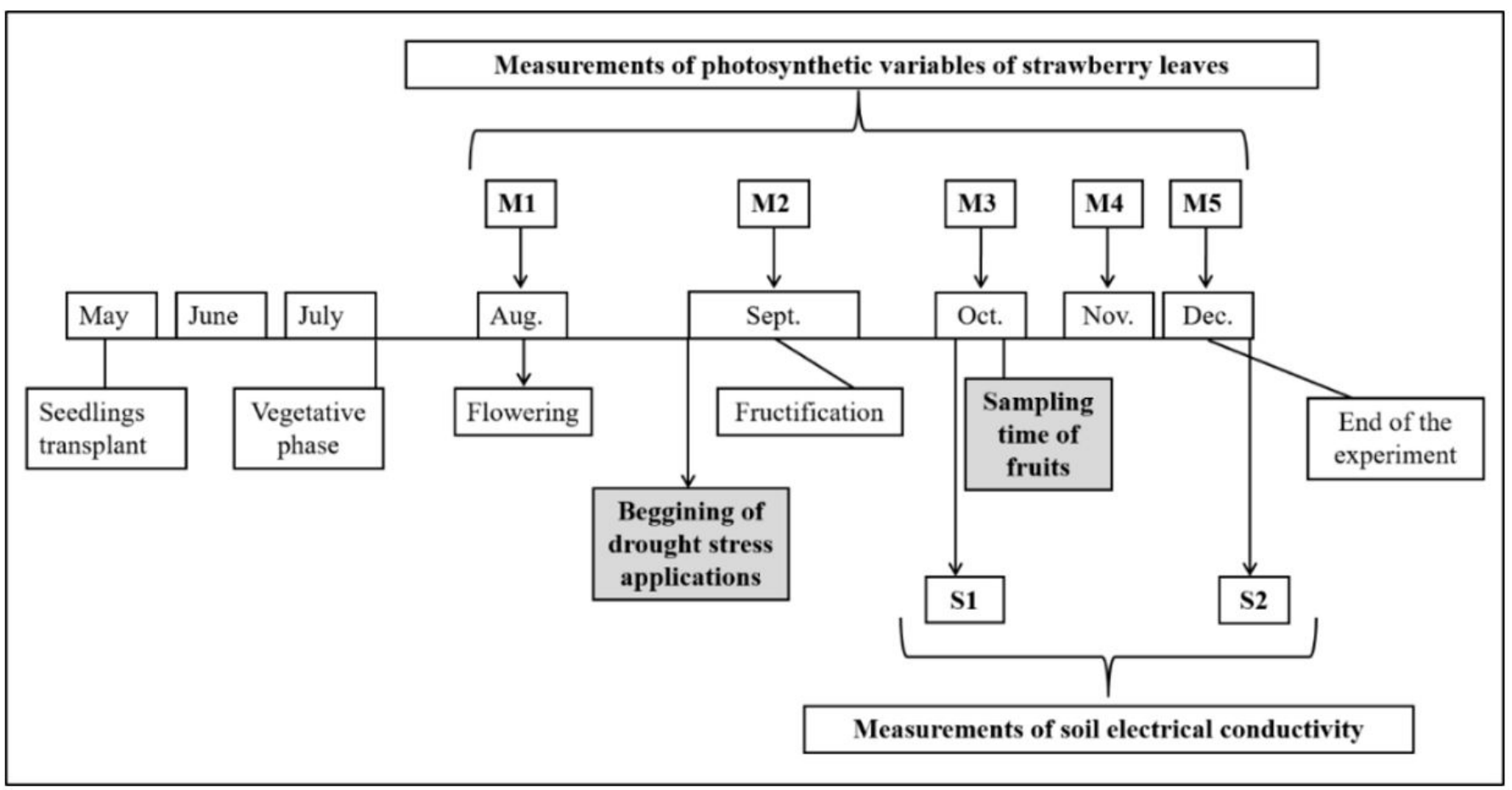

Figure 1. The development of the experiment over the months: transplanting date, vegetative phase, flowering phase, beginning of drought stress applications, fructification phase, sampling time, end of the experiment, as well as the measurements S1 and S2 of soil electrical conductivity and M1 to M5 of photosynthetic variables are shown. 
cycle. Biomass of both fresh and dried plants was determined by weighing before and after drying of the aerial portion of all the plants at the end of the experiment, in an oven at $60^{\circ} \mathrm{C}$ with air circulation.

\subsection{Quantification of minerals in the strawberry leaf and fruit and reducing sugars and sucrose in the fruit}

The quantification of the minerals occurred in fruit and leaves previously lyophilized, by the sample digested (250 $\mathrm{mg}$ of sample) with $\mathrm{H}_{2} \mathrm{O}_{2}$ and $(1 \mathrm{~mL}) \mathrm{HNO}_{3}(5 \mathrm{~mL})$ in a microwave using the method of Silva (2009), by atomic absorption spectrometry (Varian $^{\mathrm{TM}}$ AA240FS, Santa Clara, CA). Were determined the contents of magnesium $(\mathrm{Mg})$, phosphorus $(\mathrm{P})$, copper $(\mathrm{Cu})$, calcium $(\mathrm{Ca})$, manganese $(\mathrm{Mn})$, potassium $(\mathrm{K})$, and boron (B). The quantification of sucrose and reducing sugars in the lyophilized strawberry fruit was performed by spectrometry by the method described by Nelson (1944). Mean values of both the samples were expressed as 'grams per kilogram of fruit in dry weight' (DW) ( $\mathrm{g} \mathrm{kg}^{-1} \mathrm{DW}$ fruit).

\subsection{Quantification of total anthocyanins, L-ascorbic acid, total phenolics, antioxidant activity, and enzymatic activity of polyphenol oxidase (PPO) and peroxidase (POD), in strawberry fruit}

All the experiments were performed in lyophilized strawberry fruit. The estimation of total phenolic compounds, total anthocyanin and the total antioxidant activity were performed as previously described by Galli et al. (2016). The content of L-ascorbic acid in the strawberry fruit was determined as described by Vinci et al. (1995) by high-performance liquid chromatography (HPLC) on a reverse phase column (RP-18, $5 \mu \mathrm{m}, 4.6 \times 250 \mathrm{~mm}$ ), using a liquid chromatography system (Shimadzu LC-10AT equipped with UV detector system). The chromatographic conditions were: flow rate of $0.8 \mathrm{~mL} \mathrm{~min}^{-1}$ with detection at $254 \mathrm{~nm}, 10 \mu \mathrm{L}$ injection volume, the mobile phase was $100 \%$ methanol and a solution of $0.1 \%$ acetic acid in ultrapure water. A standard used was L-Ascorbic acid (Sigma-Aldrich). The results were expressed in grams of L-ascorbic acid per kilogram of DW fruit ( $\mathrm{g} \mathrm{L}$-ascorbic acid $\mathrm{kg} \mathrm{DW}$ fruit $^{-1}$ ). The activity of polyphenol oxidase (PPO, EC 1.14.18.1) and peroxidase (PO, EC 1.11.1) were determined by spectrophotometry according to the method of Campos et al. (2004).

\subsection{Relative expression of genes related to the phenylpropanoids pathway in strawberry fruit}

The isolation of total RNA, cDNA synthesis and amplification by RT-qPCR were performed as described by Galli et al. (2015). Was evaluated the expression of the key genes related to the phenylpropanoids pathway: genes encoding phenylalanine ammonia lyase (PAL), chalcone synthase (CHS), leucoanthocyanidin reductase (LAR), and UDP flavonoid glycosyltransferase (UFGT). We also evaluated the expression of key genes encoding GDP-D-mannose-3, 5-epimerase (GME) and L-galactono-1,4-lactone dehydrogenase $(\mathrm{GLDH})$ related to the ascorbate pathway. The reference genes utilized to normalize the transcript levels were as follows: genes encoding pyruvate decarboxylase (PIRUV_DESCARB), ubiquitin protein (UBQ11) and histone H4 (HISTH4). These genes were selected according to previous experiments performed in our laboratory (Galli et al., 2015).

\subsection{Statistical analysis}

The computer program, SAS System for Windows version 9.1.3. (Statistical Analysis System, 2000) was used to perform all the statistical analyses. The data were subjected to variance analysis. After to check statistical significance, we compared the treatments by employing Tukey's test. Data were recorded as mean \pm standard deviation and relative expressions of the transcripts were recorded as mean \pm standard error. Pearson's correlation was used to correlate the variables. The results were considered to be statistically significant if the $\mathrm{p}$-value was less than or equal to 0.05 ( $\mathrm{p} \leq 0.05)$.

\section{Results}

3.1 Drought stress on photosynthetic variables of leaves, on soil electrical conductivity, on the yield of fruit, and on plant biomass in the greenhouse

As expected, the strawberry plants from the L1 and L2 (levels of the stress) showed a dose-dependent and significant reduction in the photosynthetic variables, being them $\mathrm{CO}_{2}$ assimilation rate (in M3, M4 and M5 measurements), transpiration rate (in M4 and M5), and stomatal conductance (in M4 and M5) (Figure $2 \mathrm{a}-\mathrm{c}$ ). For example, in the last measurement (M5), there was a statistically significant reduction of $29.16 \%$ and $58.69 \%$ of $\mathrm{CO}_{2}$ assimilation rate in the $\mathrm{L} 1$ and $\mathrm{L} 2$ treatments, respectively, compared to the control treatment. Furthermore, compared to the control, there was a reduction of $30.86 \%$ and $80.58 \%$ of transpiration rate, and $33.02 \%$ and $81.32 \%$ of stomatal conductance in the L1 and L2 treatments, respectively. Occurred also a reduction in these variables for the whole duration of the crop cycle in all treatments (Figure $2 \mathrm{a}-\mathrm{c}$ ).

As shown in Figure 2 (d), the soil electrical conductivity was significantly higher in L2 (1900.51 and $2440.33 \mu \mathrm{S} \mathrm{cm}^{-1}$ in the S1 and S2, respectively) than in L1 (1540.42 and $2000.75 \mu \mathrm{Scm}^{-1}$ in the $\mathrm{S} 1$ and $\mathrm{S} 2$, respectively) and in the control treatments (1280.37 and $1890.73 \mu \mathrm{S} \mathrm{cm}^{-1}$ in the S1 and S2, respectively). These results indicate that there was a higher content of ionic solutes in the soil of the L2 treatment.

We also evaluated the plant biomass and fruit yield of strawberry plants under DS and observed a statistically significant ( $\mathrm{p} \leq 0.05$ ) reduction of $30.97 \%$ for $\mathrm{L} 1$ and $57.36 \%$ for $\mathrm{L} 2$ in the plant biomass, and a reduction of $32.47 \%$ for $\mathrm{L} 1$ and $50.65 \%$ for L2 in the fruit yield, compared to the control treatment (Table 1).

\subsection{Effect of drought stress on the oxidant enzymatic activity in strawberry fruit}

We assessed the activity of peroxidases (PO) and polyphenol oxidases (PPO) enzymes to verify the effect of strawberry plants under DS. The results showed that the activity of PO and PPO enzymes was significantly higher $(\mathrm{p} \leq 0.05)$ in plants of L2 (67.47\% for PO and $133.60 \%$ for PPO), compared to control, thus suggesting that oxidative stress was induced in the fruit (Figure $3 \mathrm{a}$ and $\mathrm{b}$ ). 
(a)

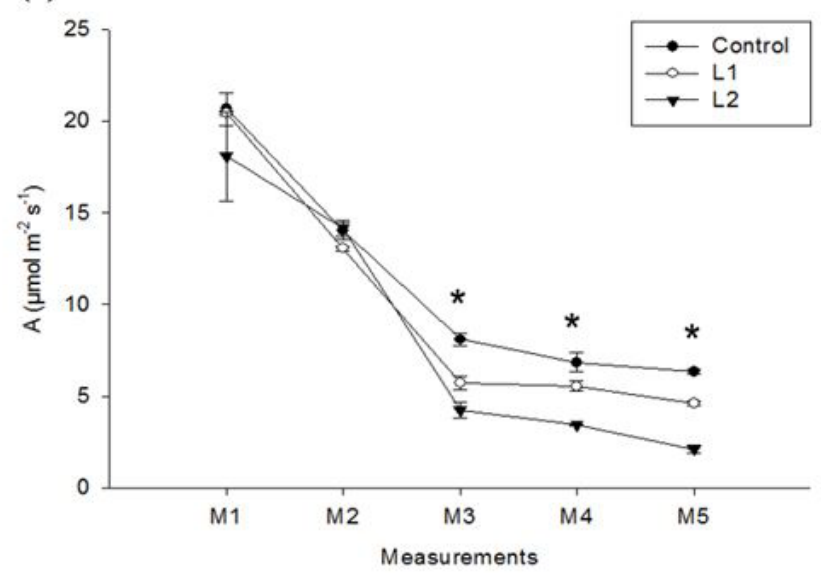

(c)

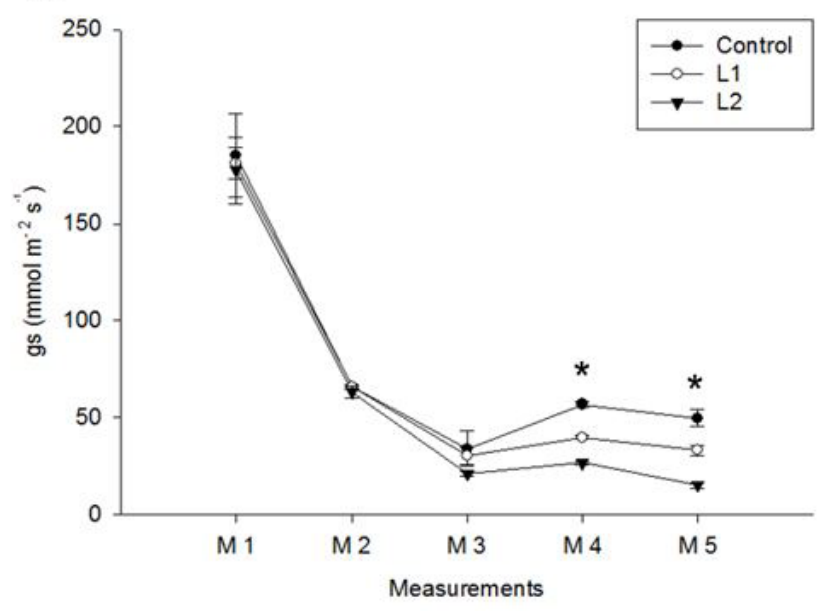

(b)

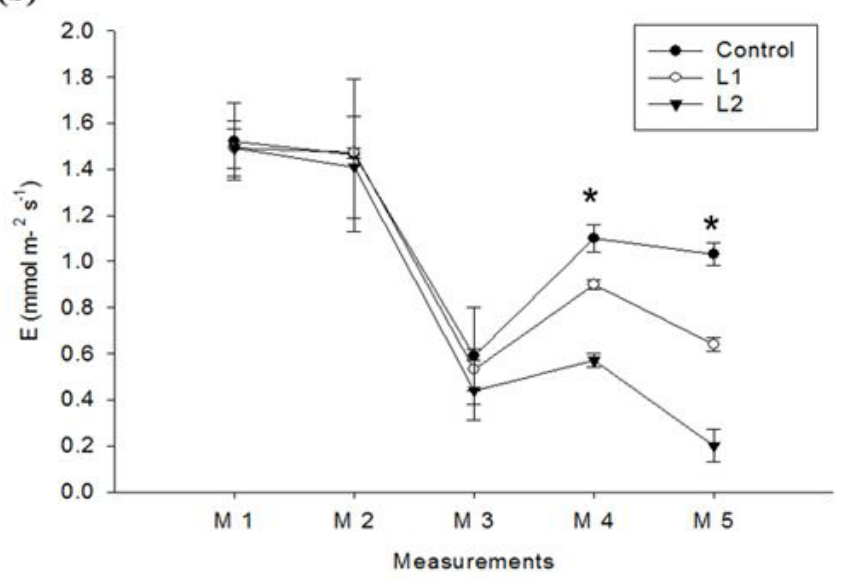

(d)

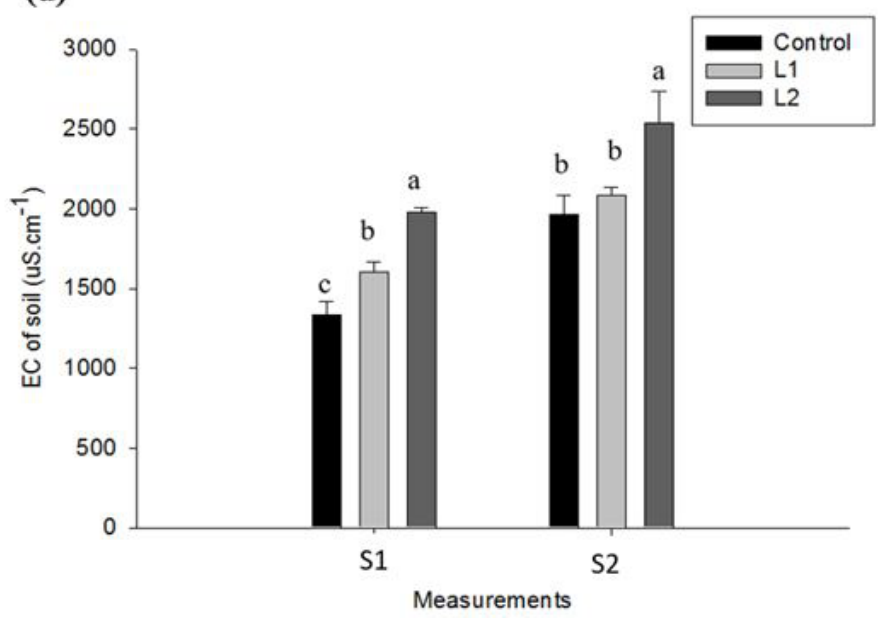

Figure 2. Quantification of photosynthetic variables and soil electrical conductivity. $\mathrm{A}-\mathrm{CO}_{2}$ assimilation rate (a), E - transpiration rate (b), gs - stomatal conductance (c) and EC of soil - soil electrical conductivity (d). Strawberry plants Camarosa cv. were water irrigated with an amount corresponding to $100 \%$ of crop evapotranspiration (ETc) (Control), 70\% of ETc (L1), or 50\% of ETc (L2). The measurements of soil electrical conductivity (S1 and S2) and photosynthetic variables (M1-M5) (Figure 1). The means of four replicates \pm SD are shown. Different letters and asterisk $\left(^{*}\right)$ indicate statistical difference $(P<0.05)$ by Tukey’s test.

Table 1. The fresh and dry plant biomas and yield of fruit of strawberry plants. Control (100\% of crop ETc), L1 (70\% of crop ETc) and L2 (50\% of ETc). Different letters indicate statistical difference $(P<0.05)$ by Tukey's test between the treatments for the same variable. The means of four replicates \pm SD are shown.

\begin{tabular}{crrr}
\hline Variables & \multicolumn{1}{c}{ Control } & \multicolumn{1}{c}{ L1 } & \multicolumn{1}{c}{ L2 } \\
\hline Fresh Biomass & $51.34 \pm 3.62 \mathrm{a}$ & $35.44 \pm 2.42 \mathrm{~b}$ & $21.89 \pm 2.13 \mathrm{c}$ \\
Dry Biomass & $12.68 \pm 1.82 \mathrm{a}$ & $8.96 \pm 1.09 \mathrm{~b}$ & $6.79 \pm 0.91 \mathrm{c}$ \\
Yield & $226.48 \pm 9.91 \mathrm{a}$ & $152.95 \pm 3.52 \mathrm{~b}$ & $111.77 \pm 2.20 \mathrm{c}$ \\
\hline
\end{tabular}

\subsection{Effect of drought stress on the content of minerals, reducing sugars, and sucrose}

As shown in Table 2, the DS in L1 and L2 treatments significantly impaired the absorption and accumulation of $\mathrm{B}$ in the fruit, and $\mathrm{Cu}$ in the leaves of strawberry plants. On the contrary, a significantly increased $(p \leq 0.05)$ in the leaves of DS plants occurred for $\mathrm{Mn}$ and $\mathrm{K}$. The content of $\mathrm{Mg}$ and $\mathrm{P}$ in the fruit and in the leave was not affected by the stress.
Moreover, the reducing sugars (12\%) and sucrose content (23\%) (Figure $3 \mathrm{c}$ and d, respectively) were significantly higher in L2 treatment, compared to control. Therefore, the DS applied seems to have modified the content of minerals and sugars accumulated in the strawberry plants.

\subsection{Effect of drought stress on the accumulation of antioxidant compounds and on the expression of related genes}

The DS levels affected in general variables as content of phenolic compounds (Figure 3e), anthocyanins (Figure 3f), L-ascorbic acid (Figure 3g), as well as the total antioxidant activity (Figure 3h). Specifically, the content of phenolic compounds showed a significant improvement of $29 \%(\mathrm{p} \leq 0.05)$ in the L1 and $36 \%$ in the $\mathrm{L} 2$ treatments, compared to the control. The total antioxidant activity was improved by $27 \%$ in both the stress treatments. In contrast, the content of anthocyanins was reduced by $26.52 \%$ in L1, compared to the control. The increased content of phenolic compounds in plants under DS was most likely 
(a)

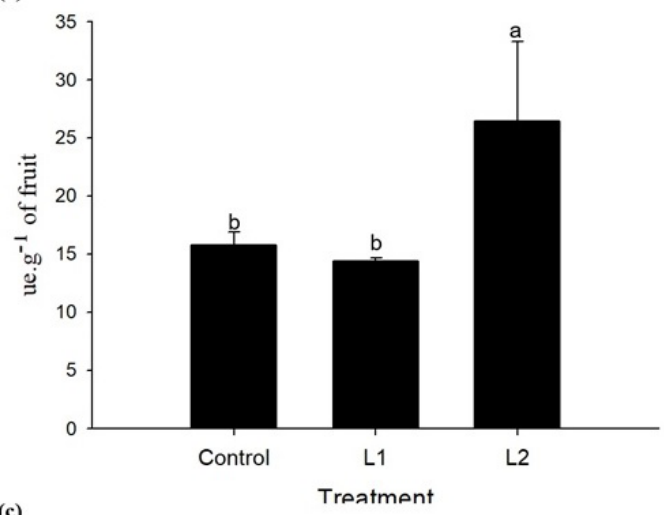

(c)

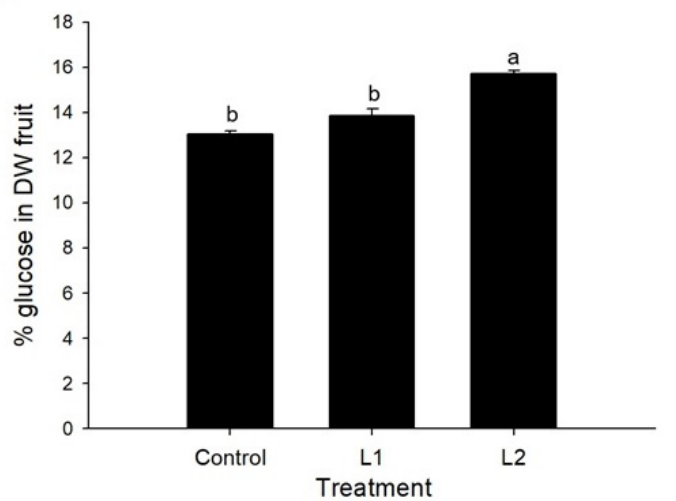

(e)

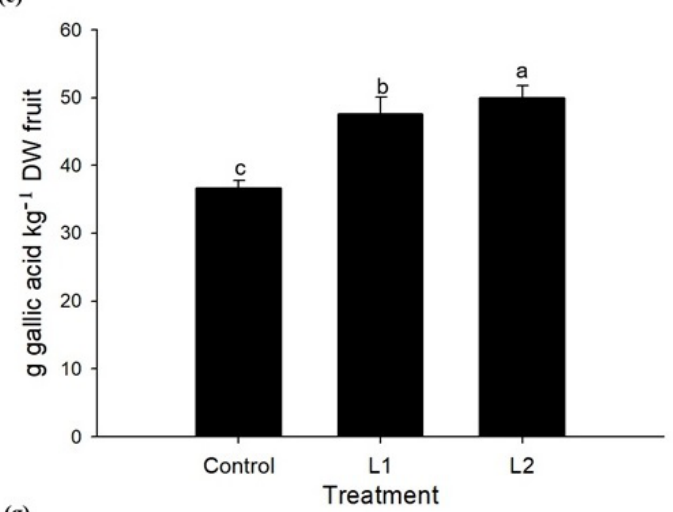

(g)

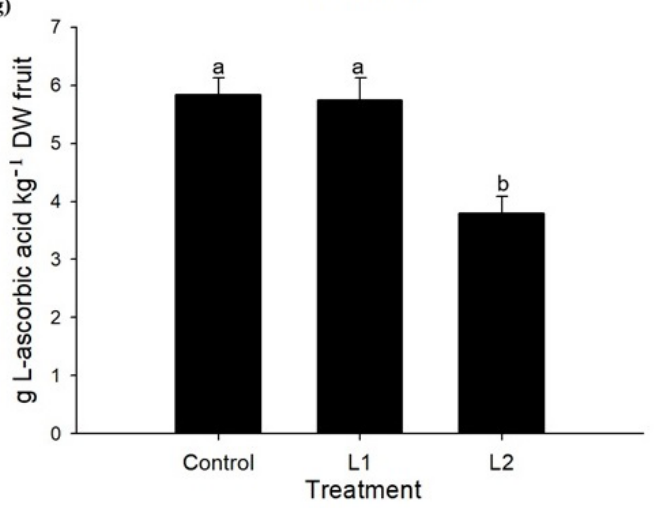

(b)

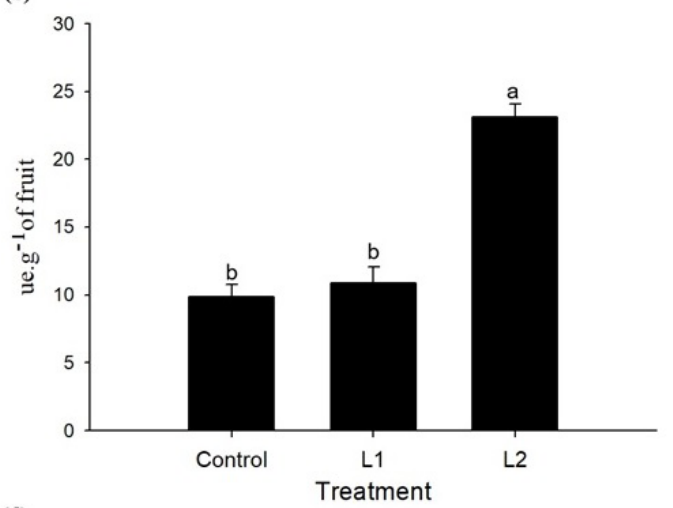

(d)
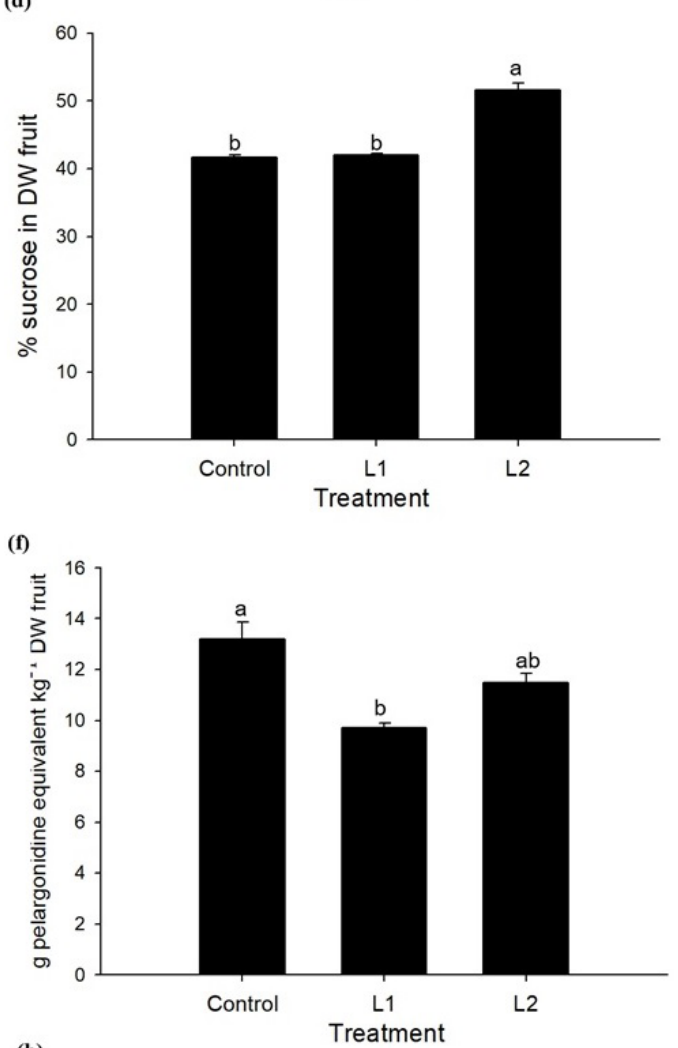

(h)

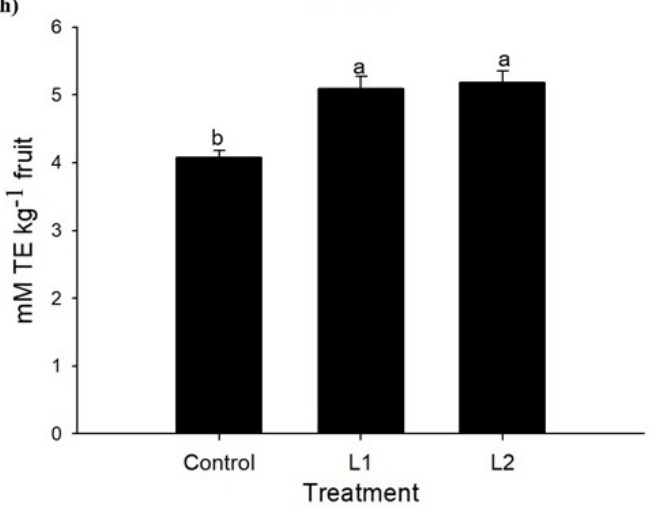

Figure 3. Quantification of metabolites and enzymatic activity. Enzymatic activity of peroxidase (PO) (a), enzymatic activity of polyphenol oxidase (PPO) (b), content of reducing sugars (\% of glucose in DW fruit $\left.{ }^{-1}\right)(\mathbf{c})$, content of sucrose (\% of sucrose in DW fruit $\left.{ }^{-1}\right)(\mathbf{d})$, total phenolic content ( $\left.\mathrm{g} \mathrm{kg} \mathrm{DW} \mathrm{fruit}^{-1}\right)(\mathbf{e})$, total anthocyanins ( $\left.\mathrm{g} \mathrm{kg} \mathrm{DW} \mathrm{fruit}^{-1}\right)(\mathbf{f})$, L-ascorbic acid (g kg DW fruit ${ }^{-1}$ ) (g), and total antioxidant activity $\left(\mathrm{mM} \mathrm{TE} \mathrm{g}^{-1}\right)$ (h) from strawberry fruit. Strawberry plants Camarosa cv. were water irrigated with an amount corresponding to $100 \%$ of crop evapotranspiration (ETc) (Control), $70 \%$ of ETc (L1), or 50\% of ETc (L2). The means of four replicates \pm SD are shown. Different letters indicate statistical difference $(P<0.05)$ by Tukey's test. 
Table 2. Mineral composition of strawberry fruit and leaves. Strawberry plants Camarosa cv. were water irrigated with an amount corresponding to $100 \%$ of crop evapotranspiration (ETc) (Control), $70 \%$ of crop ETc (L1), or 50\% of ETc (L2). Data are expressed in $\mathrm{g} \mathrm{kg}^{-1}$ on the DW basis. The means of four replicates \pm SD are shown. The content of each mineral was compared between the three treatments. Therefore, different letters indicate statistical difference $(P<0.05)$ by Tukey's test between the treatments from the same row. ns - not significant.

\begin{tabular}{|c|c|c|c|c|c|}
\hline Treatments & $\mathrm{Ca}$ & $\mathrm{K}$ & Mn & $\mathrm{Cu}$ & B \\
\hline \multicolumn{6}{|l|}{ Fruit } \\
\hline $\mathrm{C}$ & $2.39 \pm 0.29 \mathrm{ab}$ & $14.99 \pm 0.62 \mathrm{~ns}$ & $0.0204 \pm 0.0018 \mathrm{~ns}$ & $0.003 \pm 0.0001 \mathrm{~ns}$ & $0.00016 \pm 0.00001 \mathrm{a}$ \\
\hline L1 & $2.62 \pm 0.09 a$ & $14.36 \pm 0.34$ & $0.0272 \pm 0.032$ & $0.003 \pm 0.0002$ & $0.00006 \pm 0.00001 \mathrm{~b}$ \\
\hline L2 & $2.02 \pm 0.08 b$ & $13.61 \pm 2.77$ & $0.0245 \pm 0.09$ & $0.003 \pm 0.0006$ & $0.00006 \pm 0.00001 \mathrm{~b}$ \\
\hline \multicolumn{6}{|l|}{ Leaves } \\
\hline $\mathrm{C}$ & $11.27 \pm 0.47 \mathrm{~ns}$ & $15.96 \pm 3.26 \mathrm{~b}$ & $0.087 \pm 0.011 b$ & $0.024 \pm 0.003 \mathrm{a}$ & $0.00057 \pm 0.00002 \mathrm{~ns}$ \\
\hline L1 & $12.09 \pm 0.08$ & $19.86 \pm 1.75 \mathrm{a}$ & $0.114 \pm 0.016 \mathrm{a}$ & $0.009 \pm 0.0003 \mathrm{~b}$ & $0.00057 \pm 0.00001$ \\
\hline L2 & $11.81 \pm 0.43$ & $19.13 \pm 1.83 \mathrm{a}$ & $0.115 \pm 0.026 \mathrm{a}$ & $0.005 \pm 0.0007 c$ & $0.00067 \pm 0.00009$ \\
\hline
\end{tabular}

related to the increased expression of $P A L$ gene, as observed in Figure 4a. In the same metabolic pathway, we also observed a downregulation of the CHS gene (Figure $4 \mathrm{~b}$ ) (related to the synthesis of chalcones), with an RQ value of 0.39 in the L1 and 0.73 in the L2; and UFGT gene (related to the glycosylation of anthocyanins), with an RQ of 0.33 and 0.71 in the L1 and L2, respectively (Figure $4 \mathrm{~d}$ ). The LAR gene (related to the synthesis of catechins) was downregulated only in L1 treatment, with an RQ of 0.62 (Figure 4c). On the contrary, the expression of ANR gene (related to the synthesis of anthocyanidins) was not affected by the treatments. The downregulation of these genes may have played a role in the reduced content of anthocyanins in strawberry fruit of L1 (Figure 3f). Similarly, the L-ascorbic acid content was reduced in fruit in the $\mathrm{L} 2$ treatment $\left(3.79 \pm 0.30 \mathrm{~g} \mathrm{~kg}^{-1}\right)$, compared to L1 $\left(5.74 \pm 0.38 \mathrm{~g} \mathrm{~kg}^{-1}\right)$ and control treatments $\left(5.85 \pm 0.29 \mathrm{~g} \mathrm{~kg}^{-1}\right)$ (Figure $3 \mathrm{~g}$ ). The decreased content of L-ascorbic acid in fruit under DS was accompanied by the downregulation of GME (Figure 4e) and GLDH (Figure 4f) genes.

\section{Discussion}

Strawberry plants require regular irrigation because they are very sensitive to drought stress (DS) (Anjum et al., 2011). To ensure that strawberry production keeps up with an increasing demand, a complete understanding of the processes involved in the yield and quality of the fruit under DS conditions is required. Therefore, we evaluated the effect of DS on a set of variables related to the production and quality of strawberry fruit. In this study, the plants showed reduced levels of transpiration rate and stomatal conductance to avoid water loss as a result of the stress, which may have been a consequence of stomatal closure (Figure $2 \mathrm{c}$ and $\mathrm{d}$ ). This stomatal closure is one of the well-documented effects of DS (Damour et al., 2010). A mechanism to help maintain water balance in plants is associated with a reduction in the rate of transpiration for survival. However, the reduction of this variable influences the reduction of the net absorption of $\mathrm{CO}_{2}$ (Figure 2a) for carbon assimilation by leaves (Ripoll et al., 2014). It has been reported that the reduction in the photosynthesis and the reduced supply of assimilates, observed under severe water deficiency, adversely affect leaf expansion and growth (Anjum et al., 2011). In fact, in the present study, beside the reduced photosynthetic parameters, plants under DS showed reduced yield and biomass. This result indicates that, in order to use the application of DS as a biofortification approach it is necessary to evaluate lower levels of stress, seeking for one that is able to induce functional compounds and does not significantly affect fruit yield. Furthermore, the values of the evaluated photosynthetic variables were reduced throughout the experiment. This reduction was also observed by Orsini et al. (2012) by measuring the photosynthetic variables of strawberry plant at 2 and 58 days after salt stress $(\mathrm{NaCl})$ treatment. Therefore, this result may be related to the stage of crop cycle. It might also be caused by an increase in the environmental temperature (from $15.32{ }^{\circ} \mathrm{C}$ to $27.42^{\circ} \mathrm{C}$ ) and a reduction in the relative humidity (from $86.67 \%$ to $60.92 \%$ ) for the whole duration of the experiment. In summary, the reduction of water absorption may have induced stomatal closure in order to reduce evapotranspiration and consequently may have reduced photosynthesis and yield, as observed in similar studies with strawberry plants (Grant et al., 2012; Orsini et al., 2012).

In addition, these stressed plants showed lower accumulation of some minerals $(\mathrm{Ca}, \mathrm{Cu}$ and $\mathrm{B}$ in the fruit, and $\mathrm{Cu}$ in the leaves) (Table 2). Minerals generally act as important enzymatic cofactors of several enzymes, such as $\mathrm{Cu}$ and $\mathrm{B}$, besides having other essential roles in the metabolism of photosynthesis. In addition, other minerals such as calcium act by regulating various processes (Batistič \& Kudla, 2012). Therefore, the association of reduced photosynthesis and reduced accumulation of minerals may have resulted in plants having a lower biomass and fruit production (Table 1), which is an expected effect of DS. Otherwise, the content of $\mathrm{K}$ was higher in the leaves of stressed plants compared to non-stressed plants as was observed by Keutgen et al. (2005) in strawberry plants under conditions of osmotic stress. This result might be because stressed plants showed lower biomass, which suggests that the $\mathrm{K}$ uptake was concentrated in the cells. (Table 2). The enhanced levels of K may also represent a tolerance mechanism to avoid the absorption of toxic ions from the roots. According to Keutgen \& Pawelzik (2008), in berry fruits, K improves visual and turgor maintenance, but may reduce fruit size.

The DS also induced the activity of PO and PPO enzymes (Figure $3 \mathrm{a}$ and $\mathrm{b}$ ). When an imbalance occurs between compounds with antioxidant potential and free radicals, it leads to the formation of the so-called oxidative stress, in which these enzymes are usually produced. (Gill \& Tuteja, 2010). Since these 
(a)

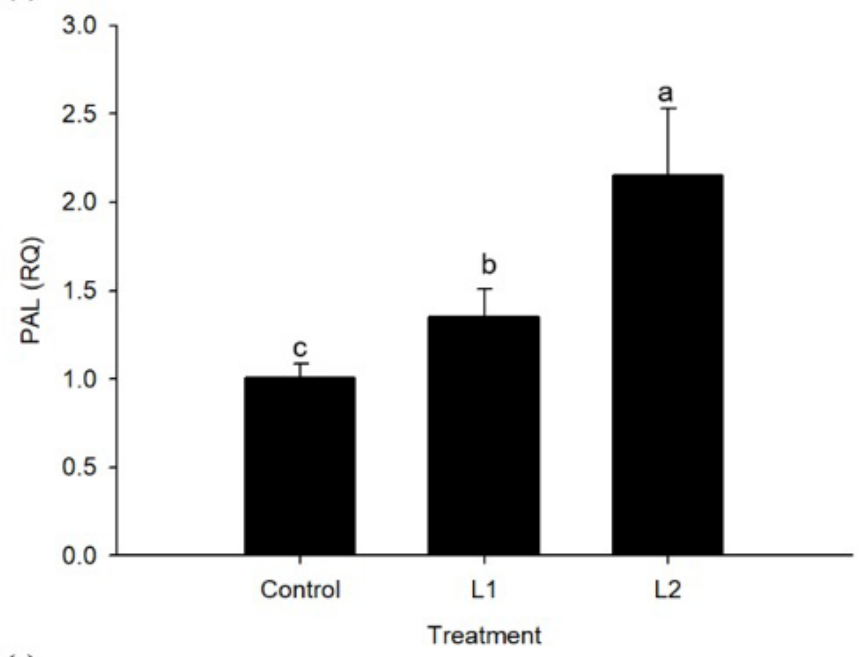

(c)

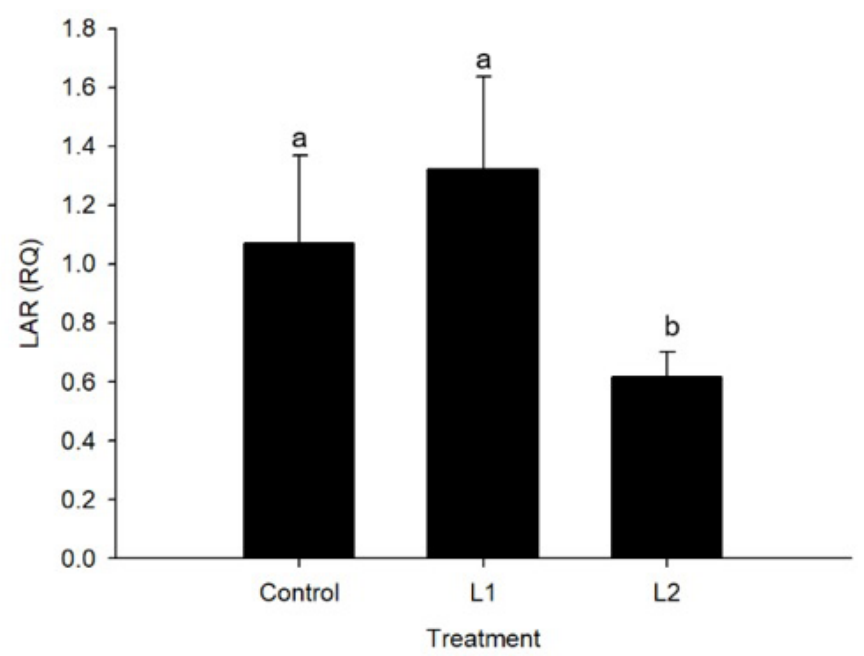

(e)

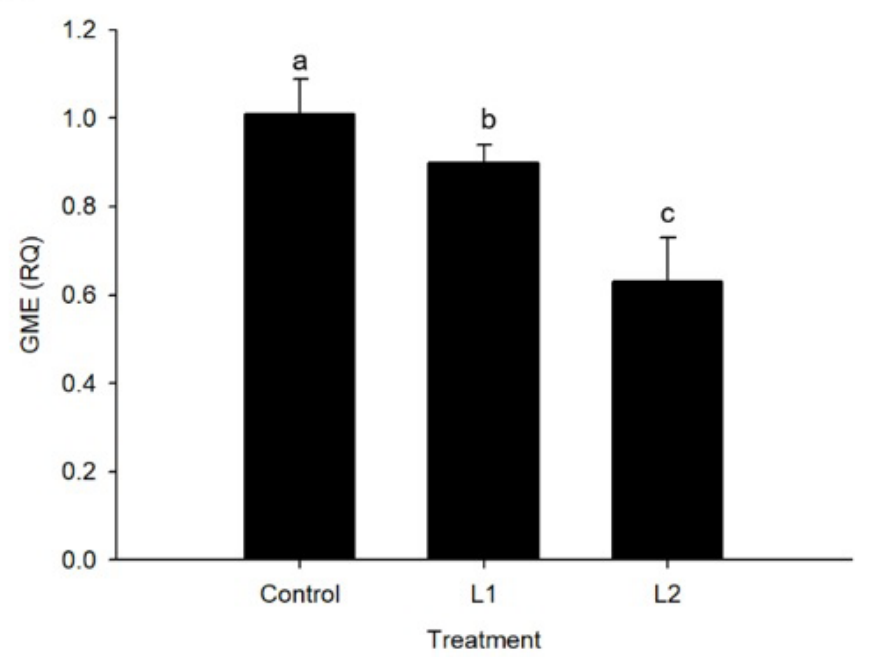

(b)

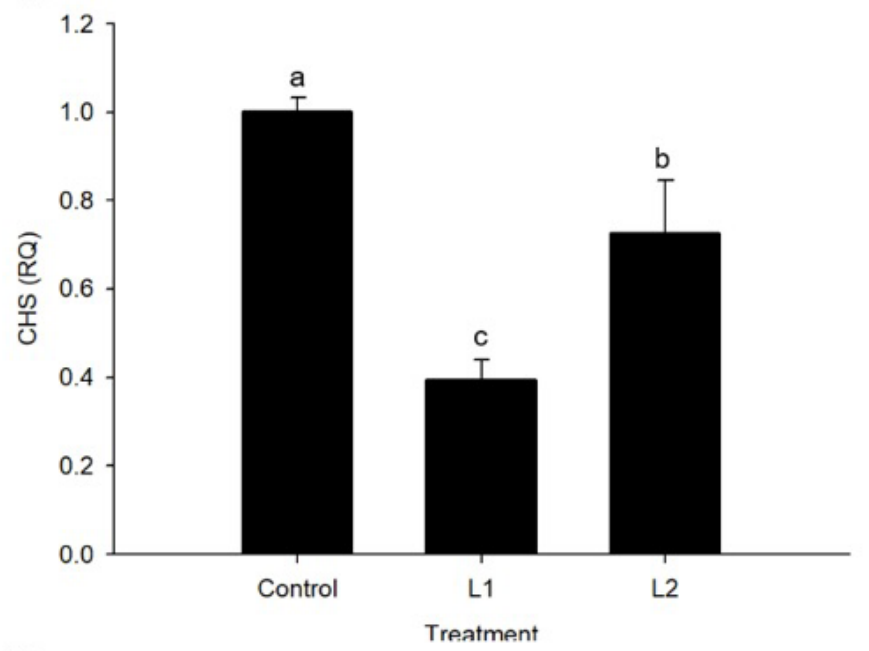

(d)

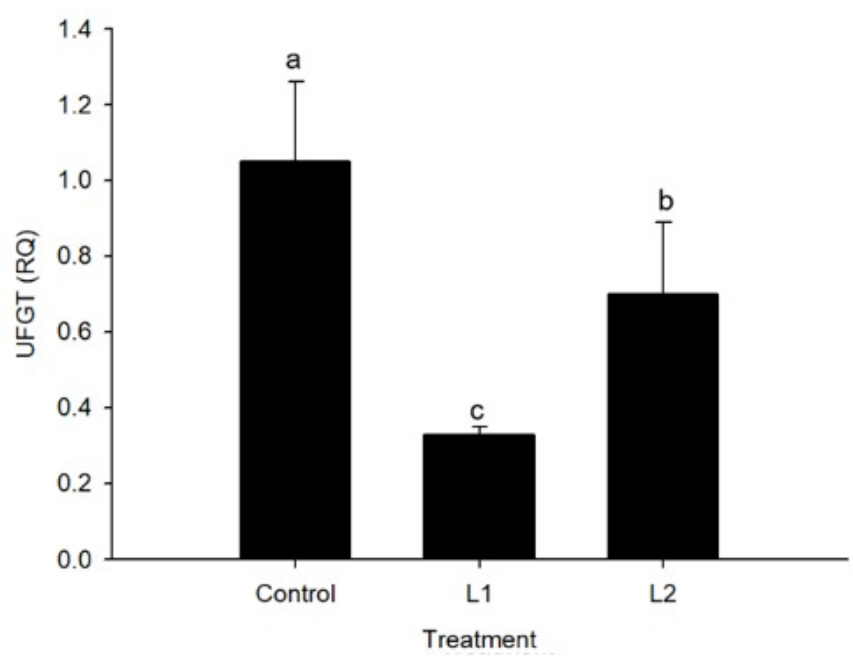

(f)

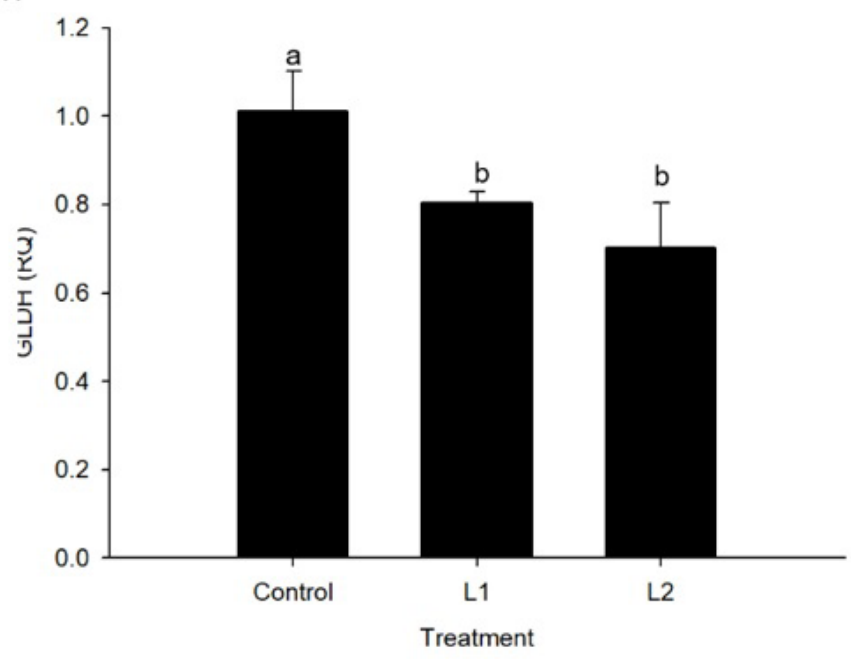

Figure 4. Gene expression analysis in strawberry fruit. Results as shown as relative expression (RQ) using Control treatment as the reference treatment. PAL (phenylalanine ammonia lyase) (a), CHS (chalcone synthase) (b), LAR (leucoanthocyanidin reductase) (c), UFGT (UDP flavonoid glycosyl transferase) (d), GME (GDP-mannose-3,5-epimerase) (e), GLDH (L-galactono-1,4-lactone dehydrogenase) (f). Strawberry plants Camarosa cv. were water irrigated with an amount corresponding to 100\% of crop evapotranspiration (ETc) (Control), 70\% of ETc (L1), or 50\% of ETc (L2). The means of four replicates \pm SD are shown. Different letters indicate statistical difference $(\mathrm{P}<0.05)$ by Tukey's test. 
enzymes are also produced under other physiological conditions, the determination of $\mathrm{H}_{2} \mathrm{O}_{2}$ content in further experiments might reflect whether oxidative stress represents a significant effect on strawberry fruit under drought stress. Despite that, the drought stress stimulated the accumulation of antioxidant compounds, suggesting that an oxidative response was taken place. Antioxidant compounds are usually induced in plants as a defense response under stress conditions. Because these compounds provide health benefits for humans, several studies have suggested the application of controlled abiotic stresses as an effort for biofortification in order to improve the content of antioxidant compounds (Lichtenthaler, 2004). It has been proposed that reactive oxygen species (ROS) formed during DS may indirectly orchestrate the phenylpropanoids and flavonoids biosynthetic pathways, through the initiation of phosphorylation cascades by $\mathrm{H}_{2} \mathrm{O}_{2}$ that are highly activated during this stress condition (Grassmann et al., 2002). In accordance with these studies, we observed that the higher levels of antioxidant activity in fruit from the stressed plants were mostly related to higher levels of phenolic compounds (Figure 3e) which, in turn, were most probably associated with a higher expression of PAL gene.

The metabolic pathway that produces phenolic compounds (via the phenylpropanoids) is precursor cinnamic acid, which is produced by the desanimation of L-phenylalanine by the PAL enzyme. In our study, we have evaluated the expression of PAL gene to monitor the overall activity of flavonoid phenylpropanoid pathway (Figure 4). Our results indicate a close relationship between the content of phenolic compounds in fruit and the PAL transcription of the stressed plants, which is in agreement with previous studies related to abiotic stress response in lettuce and vanilla (Fock-Bastide et al., 2014). We also observed that the content of anthocyanins was reduced in fruit from both levels of the water-stress, which moderately correlated (0.72) with the downregulation of UFGT genes, strictly required for anthocyanin biosynthesis and storage. Weber et al. (2017) also observed a similar reduction in the anthocyanin content; however, the reduction and/or increase in the content of these compounds was cultivar dependent. CHS (in both levels) and LAR (in L2 level) genes were also downregulated by the drought stress. This result indicates that non-flavonoid (phenolic compounds) rather than flavonoid (anthocyanins and anthocyanidins) were preferentially induced by this adverse condition, as was observed in soybean cultivated under drought stress (Gutierrez-Gonzalez et al., 2010).

Similarly, the content of L-ascorbic acid was lower in the DS plants, which was most likely related to the downregulation of GME (chosen because it encodes an enzyme at the beginning of the metabolic pathway) and GLDH (chosen because it encodes an enzyme directly related to the synthesis of L-ascorbic acid), with a moderate correlation of 0.67 and 0.72 , respectively. Although L-ascorbic acid seems to play an important role as a radical scavenger during stress conditions, studies have reported that in strawberry fruit the effect of DS on the ascorbic acid content is genotype-dependent (Cruz-Rus et al., 2011). Overall, in our studies, there was a close relationship between content of antioxidant compounds and transcript accumulation, thus indicating that physiological and transcription responses occur simultaneously.
In addition to an increased content of the antioxidant compounds, the DS plants accumulated higher content of sugars in the cytosol, which are the main components of dry matter in the strawberry fruit, in order to lower osmotic potential, thereby maintaining cell turgor (Razavi et al., 2011). The induction of sugars in water stressed strawberry has been previously reported (Terry et al., 2007; Giné-Bordonaba \& Terry, 2010; Giné-Bordonaba \& Terry, 2016). Some responses have already been observed and may be suggested: as a possible attempt of the plant to adjust its metabolism in order to maintain the osmotic equilibrium, the application of water stress caused an increase in the concentration of sugars in the fruits, in a study conducted by Giné-Bordonaba \& Terry (2010, 2016); In addition, it should also be considered that the availability of larger quantities of water provided by irrigation may result in a lower concentration of flavor compounds when expressed on a fresh weight basis caused by "dilution effect". The accumulation of carbohydrates in plant organs has also been associated with $\mathrm{Ca}$ and other mineral deficiencies, a fact which was also verified in our study. Calcium is also involved in changes in the pressure of cell expansion and turgor. Although the mechanisms underlining the effect of Ca during DS is still under investigation, it has been proposed that the combined effect of some hormones, such as auxins and abscisic acid that use $\mathrm{Ca}$ in membrane transport mechanisms and as a secondary messenger to modify the cell turgescence and the accumulation of solutes, boosts expansion and maturation of cells (Hocking et al., 2016; Kazemi, 2014; Valentinuzzi et al., 2015).

\section{Conclusion}

This study demonstrates that drought stress (DS) modifies the absorption and accumulation of minerals $(\mathrm{Ca}, \mathrm{B}, \mathrm{Mn}, \mathrm{Cu})$ and negatively affects the photosynthetic effectiveness of strawberry plants, resulting in reduced yield and plant biomass. On the other hand, DS seems to be a promising strategy to improve the quality of strawberry fruit by increasing the content of antioxidant compounds and sugars. It may represent a strategy to reduce water usage. However, the amount of stress inflicted on the plants must be controlled carefully in order to prevent loss of yield and biomass of strawberry fruit.

\section{Acknowledgements}

The authors gratefully acknowledge the technical and financial support of Brazilian Temperate Agriculture Research (Embrapa).

\section{References}

Ali, Q., Anwar, F., Ashraf, M., Saari, N., \& Perveen, R. (2013). Ameliorating effects of exogenously applied proline on seed composition, seed oil quality and oil antioxidant activity of maize (Zea mays L.) under drought stress. International Journal of Molecular Sciences, 14(1), 818-835. http://dx.doi.org/10.3390/ijms14010818. PMid:23344043.

Anjum, S., Xie, X., \& Wang, L. (2011). Morphological, physiological and biochemical responses of plants to drought stress. African Journal of Agricultural Research, 6(9), 2026-2032.

Batistič, O. \& Kudla, J. (2012). Analysis of calcium signaling pathways in plants. Biochim Biophys Acta, 1820(8), 1283-1293. http://dx.doi. org/10.1016/j.bbagen.2011.10.012. 
Campos, Â. D., Ferreira, A. G., Hampe, M. M. V., Antunes, I. F., Brancão, N., Silveira, E. P., Osório, V. A., \& Augustin, E. (2004). Atividade de peroxidase e polifenoloxidase na resistência do feijão à antracnose. Pesquisa Agropecuária Brasileira, 39(7), 637-643. http://dx.doi. org/10.1590/S0100-204X2004000700004.

Cruz-Rus, E., Amaya, I., Sànchez-Sevilla, J. F., Botella, M. A., \& Valpuesta, V. (2011). Regulation of L-ascorbic acid content in strawberry fruit. Journal of Experimental Botany, 62(12), 4191-4201. http://dx.doi. org/10.1093/jxb/err122. PMid:21561953.

Damour, G., Simonneau, T., Cochard, H., \& Urban, L. (2010). An overview of models of stomatal conductance at the leaf level. Plant, Cell \& Environment, 33(9), 1419-1438. PMid:20545879.

Fiedor, J., \& Burda, K. (2014). Potential role of carotenoids as antioxidants in human health and disease. Nutrients, 6(2), 466-488. http://dx.doi. org/10.3390/nu6020466. PMid:24473231.

Fock-Bastide, I., Palama, T. L., Bory, S., Lécolier, A., Noirot, M., \& Joët, T. (2014). Expression profiles of key phenylpropanoid genes during Vanilla planifolia pod development reveal a positive correlation between PAL gene expression and vanillin biosynthesis. Plant Physiology and Biochemistry, 74, 304-314. http://dx.doi.org/10.1016/j. plaphy.2013.11.026. PMid:24342082.

Galli, V., Borowski, J. M., Perin, E. C., Messias, R. S., Labonde, J., Pereira, I. dos S., Silva, S., \& Rombaldi, C. V. (2015). Validation of reference genes for accurate normalization of gene expression for real timequantitative PCR in strawberry fruit using different cultivars and osmotic stresses. Gene, 554(2), 205-214. http://dx.doi.org/10.1016/j. gene.2014.10.049. PMid:25445290.

Galli, V., Messias, R. S., Perin, E. C., Borowski, J. M., Bamberg, A. L., \& Rombaldi, C. V. (2016). Mild salt stress improves strawberry fruit quality. Lebensmittel-Wissenschaft + Technologie, 73, 693-699. http:// dx.doi.org/10.1016/j.lwt.2016.07.001.

Gill, S. S., \& Tuteja, N. (2010). Reactive oxygen species and antioxidant machinery in abiotic stress tolerance in crop plants. Plant Physiology and Biochemistry, 48(12), 909-930. http://dx.doi.org/10.1016/j. plaphy.2010.08.016. PMid:20870416.

Giné-Bordonaba, J. G., \& Terry, L. A. (2010). Manipulating the tasterelated composition of strawberry fruit (Fragaria $\times$ ananassa) from different cultivars using deficit irrigation. Food Chemistry, 122(4), 1020-1026. http://dx.doi.org/10.1016/j.foodchem.2010.03.060.

Giné-Bordonaba, J., \& Terry, L. A. (2016). Effect of deficit irrigation and methyl jasmonate application on the composition of strawberry (Fragaria x ananassa) fruit and leaves. Scientia Horticulturae, 199(16), 63-70. http://dx.doi.org/10.1016/j.scienta.2015.12.026.

Grant, O. M., Davies, M. J., Johnson, A. W., \& Simpson, D. W. (2012). Physiological and growth responses to water deficits in cultivated strawberry (Fragariaxananassa) and in one of its progenitors, Fragaria chiloensis. Environmental and Experimental Botany, 83, 23-32. http://dx.doi.org/10.1016/j.envexpbot.2012.04.004.

Grassmann, J., Hippeli, S., \& Elstner, E. F. (2002). Plant's defence and its benefits for animals and medicine: Role of phenolics and terpenoids in avoiding oxygen stress. Plant Physiology and Biochemistry, 40(68), 471-478. http://dx.doi.org/10.1016/S0981-9428(02)01395-5.

Gulen, H., Kesici, M., Cetinkaya, C., \& Ergin, S. (2018). Proline and antioxidant enzyme activities in some strawberry cultivars under drought and recovery. Notulae Botanicae Horti Agrobotanici ClujNapoca, 46(2), 1-11. http://dx.doi.org/10.15835/nbha46211077.

Gutierrez-Gonzalez, J. J., Guttikonda, S. K., Tran, L. S., Aldrich, D. L., Zhong, R., Yu, O., Nguyen, H. T., \& Sleper, D. A. (2010). Differential Expression of Isoflavone Biosynthetic Genes in Soybean During Water Deficits. Plant \& Cell Physiology, 51(6), 936-948. http://dx.doi. org/10.1093/pcp/pcq065. PMid:20430761.
Hocking, B., Tyerman, S. D., Burton, R. A., \& Gilliham, M. (2016). Fruit calcium: transport and physiology. Frontiers in Plant Science, 7(7), 569. http://dx.doi.org/10.3389/fpls.2016.00569. PMid:27200042.

Jia, H., Li, C., Chai, Y., Xing, Y., \& Shen, Y. (2013). Sucrose promotes strawberry fruit ripening by stimulation of abscisic acid biosynthesis. Pakistan Journal of Botany, 45(1), 169-175.

Kazemi, M. (2014). Influence of foliar application of iron, calcium and zinc sulfate on vegetative growth and reproductive characteristics of Strawberry cv. 'Pajaro'. Trakia Journal of Sciences, 12(1), 21-26.

Keutgen, A. J., \& Pawelzik, E. (2008). Quality and nutritional value of strawberry fruit under long term salt stress. Food Chemistry, 107(4), 1413-1420. http://dx.doi.org/10.1016/j.foodchem.2007.09.071.

Keutgen, A. J., Noga, G., \& Pawelzik, E. (2005). Cultivar-specific impairment of strawberry growth, photosynthesis, carbohydrate and nitrogen accumulation by ozone. Environmental and Experimental Botany, 53(3), 271-280. http://dx.doi.org/10.1016/j.envexpbot.2004.04.003.

Laribi, A. I., Palou, L., Intrigliolo, D. S., Nortes, P. A., Rojas-Argudo, C., Taberner, V., Bartual, J., \& Pérez-Gago, M. B. (2013). Effect of sustained and regulated deficit irrigation on fruit quality of pomegranate cv. Mollar de Elche at harvest and during cold storage. Agricultural Water Management, 125, 61-70. http://dx.doi. org/10.1016/j.agwat.2013.04.009.

Lichtenthaler, H. K. (2004). El estrés y la medida del estrés en plantas. In Roger MJR, Bonjoch NP, \& Sánchez A. La ecofisiología vegetal una ciencia de sintesis (pp. 59-111). Madrid: Thomson.

Nelson, B. (1944). A photometric adaptation of the Somogyi method for the determination of glucose. The Journal of Biological Chemistry, 153(3), 375-380.

Orsini, F., Alnayef, M., Bona, S., Maggio, A., \& Gianquinto, G. (2012). Low stomatal density and reduced transpiration facilitate strawberry adaptation to salinity. Environmental and Experimental Botany, 81, 1-10. http://dx.doi.org/10.1016/j.envexpbot.2012.02.005.

Rahimi, A., Biglarifard, A., Mirdehghan, H., \& Borghei, S. F. (2011). Influence of $\mathrm{NaCl}$ salinity on growth analysis of strawberry $\mathrm{cv}$. Camarosa. Journal of Stress Physiology \& Biochemistry, 7(4), 145-156.

Razavi, F., Keyser, E., Riek, J., \& Van Labeke, M. C. (2011). A method for testing drought tolerance in Fragaria based on fast screening for water deficit response and use of associated AFLP and EST candidate gene markers. Euphytica, 180(3), 385-409. http://dx.doi. org/10.1007/s10681-011-0398-X.

Ripoll, J., Urban, L., Staudt, M., Lopez-Lauri, F., Bidel, L. P. R., \& Bertin, N. (2014). Water shortage and quality of fleshy fruit-making the most of the unavoidable. Journal of Experimental Botany, 65(15), 4097-4117. http://dx.doi.org/10.1093/jxb/eru197. PMid:24821951.

Shahidi, F., \& Ambigaipalan, P. (2015). Phenolics and polyphenolics in foods, beverages and spices: Antioxidant activity and health effects - a review. Journal of Functional Foods, 18, Part B, 820-897. http:// dx.doi.org/10.1016/j.jff.2015.06.018.

Silva, F. C. (2009). Manual de análises químicas de solos, plantas e fertilizantes. 2. ed. Brasília: Embrapa Informação Tecnológica.

Statistical Analysis System - SAS. (2000). SAS users guide: statistics. Cary: SAS Institute.

Sun, C., Li, X., Hu, Y., Zhao, P., Xu, T., Sun, J., \& Gao, X. (2015). Proline, sugars and antioxidant enzymes respond to drought stress in the leaves of strawberry plants. Weonye Gwahag Gisulji, 33(5), 625-632. http://dx.doi.org/10.7235/hort.2015.15054.

Terry, L. A., Chope, G. A., \& Bordonaba, J. G. (2007). Effect of water deficit irrigation and inoculation with Botrytis cinereal on strawberry (Fragaria $\mathrm{x}$ ananassa) fruit quality. Journal of Agricultural and 
Food Chemistry, 55(26), 10812-10819. http://dx.doi.org/10.1021/ jf072101n. PMid:18052034.

Valentinuzzi, F., Mason, M., Scampicchio, M., Andreotti, C., Cesco, S., \& Mimmo, T. (2015). Enhancement of the bioactive compound content in strawberry fruit grown under iron and phosphorus deficiency. Journal of the Science of Food and Agriculture, 95(10), 2088-2094. http://dx.doi.org/10.1002/jsfa.6924. PMid:25244604.

Vinci, G., Botrè, F., Mele, G., \& Ruggieri, G. (1995). Ascorbic acid in fruit a liquid chromatographic investigation. Food Chemistry, 53(2), 211-214. http://dx.doi.org/10.1016/0308-8146(95)90791-5.
Weber, N., Zupanc, V., Jakopic, J., Veberic, R., Mikulic-Petkovsek, M., \& Stampar, F. (2017). Influence of deficit irrigation on strawberry (Fragaria $\mathrm{x}$ ananassa Duch.) fruit quality. Journal of the Science of Food and Agriculture, 97(3), 849-857. http://dx.doi.org/10.1002/ jsfa.7806. PMid:27197623.

Złotek, U., Świeca, M., \& Jakubczyk, A. (2014). Effect of abiotic elicitation on main health-promoting compounds, antioxidant activity and commercial quality of butter lettuce (Lactuca sativa L.). Food Chemistry, 148, 253-260. http://dx.doi.org/10.1016/j. foodchem.2013.10.031. PMid:24262554. 